\title{
EMERGENCY CORONARY BYPASS GRAFTING FOR FAILED PERCUTANEOUS CORONARY ARTERY STENTING: INCREASED COSTS AND PLATELET TRANSFUSION REQUIREMENTS AFTER THE USE OF ABCIXIMAB
}

\author{
John M. Alvarez, FRACS, Melbourne, Australia
}

The adjunctive use of abciximab (ReoPro), a platelet glycoprotein IIb/IIIa receptor antagonist, with aspirin as pretreatment for percutaneous coronary artery stenting (PTCS) has risen dramatically. ${ }^{1,2}$ Reports on the outcomes of patients who require emergency coronary bypass grafting $(\mathrm{CABG})$ for unsuccessful PTCS are scarce. ${ }^{3}$ This report documents three cases. Table I outlines cardiopulmonary bypass (CPB), hematologic, and coagulation assays. All patients had received aspirin $(300 \mathrm{mg})$ and abciximab $(0.25 \mathrm{mg} / \mathrm{kg} / 5 \mathrm{~min}$ bolus and $9 \mathrm{mg} / 500 \mathrm{ml}$ normal saline solution at $10 \mu \mathrm{g} / \mathrm{min}$ intravenous infusion) before the operation. All had a profound bleeding diathesis evident from skin incision and persisting for 4 to 5 hours after the operation.

Patients

PATIENT 1. A 38-year-old man had acute stent thrombosis 14 days after PTCS to the left anterior descending coronary artery. Cardiogenic shock ensued, necessitating emergency CABG. Ticlopidine (Ticlid) at $250 \mathrm{mg}$ twice a day had been continued since the original PTCS.

CABG with a left internal thoracic artery graft to the left anterior descending coronary artery and a saphenous vein graft to a first diagonal was performed. After reversal of heparinization, 5 units of platelets were given and the chest was closed. By 60 minutes, the mediastinal blood loss was $1500 \mathrm{ml}$. At resternotomy, no specific surgical source was evident. A $1.5 \mathrm{mg}$ dose of 1-deamino-8-Darginine vasopressin (Minirim) and a $4 \times 10^{6}$ kallikrein activation unit (KIU) dose of aprotinin (Trasylol) were given intravenously. An additional $1900 \mathrm{ml}$ blood loss occurred during the next 24 hours. The patient was discharged on postoperative day 10.

PATIENT 2. A 73-year-old man in cardiogenic shock with intraaortic balloon pump support was referred for operation with a postinfarct inferior ventricular septal rupture; PTCS to the proximal right coronary artery had been performed. The operation entailed polyethylene terephthalate (Dacron) patch closure of the ventricular septal defect and placement of four venous coronary bypass grafts. Because of the previous experience, intravenous aprotinin ("high" Hammersmith dose $\left[7 \times 10^{6}\right.$ KIU]) was given at induction, and after CPB 10 units of platelets

From the Department of Cardiothoracic Surgery, Monash Medical Centre, Clayton 3168, Melbourne, Australia.

Received for publication Sept. 7, 1997; accepted for publication Oct. 9, 1997.

J Thorac Cardiovasc Surg 1998;115:472-3

Copyright (c) 1998 by Mosby, Inc.

0022-5223/98 $\$ 5.00+0 \quad \mathbf{1 2 / 5 4 / 8 6 8 8 5}$ were given. This patient died of low cardiac output syndrome 96 hours after the operation.

PATIENT 3. A 39-year-old woman, in cardiogenic shock from an evolving anterolateral acute myocardial infarction after PTCS to the circumflex coronary artery required emergency CABG. A left internal thoracic artery graft to the left anterior descending coronary artery and two additional venous bypass grafts were performed. "High" Hammersmith dose aprotinin was used (total $5 \times 10^{6}$ KIU); after CPB, 10 units of platelets were also given. The patient was discharged home 6 days after the operation.

Discussion. This limited experience focuses attention on the potential impact of abciximab on patients undergoing emergency CABG; the message is sharp. In all three cases, results of history, physical examination, and hematologic and coagulation assays were normal before the operation, yet perioperative blood loss was in excess of what was expected. Aprotinin in the "high" Hammersmith dose and immediate, repeated platelet transfusions after $\mathrm{CPB}$ appear necessary and effective in reducing mediastinal blood loss.

Abciximab use is based on the reduction in the 30-day primary end point (death, acute myocardial infarction, revascularization) reported by the $\mathrm{EPIC}^{1}$ (placebo $12.8 \%$ vs treated $8.5 \%$ ), EPILOG ${ }^{2}$ (placebo $11.7 \%$ vs treated $5.2 \%$ ), and CAPTURE (placebo $15.9 \%$ vs treated $11.3 \%$ ) trials. ${ }^{1,2}$ Only the EPIC trial reported on patients requir-

Table I. Hematologic, coagulation, and cardiopulmonary data before and after bypass

\begin{tabular}{|c|c|c|c|c|c|c|}
\hline & \multicolumn{2}{|c|}{ Case 1} & \multicolumn{2}{|c|}{ Case 2} & \multicolumn{2}{|c|}{ Case 3} \\
\hline & Before & After & Before & After & Before & After \\
\hline $\mathrm{Hb}(\mathrm{gm} / \mathrm{dl})$ & 14.3 & 10.3 & 13.6 & 9.6 & 12.9 & 9.5 \\
\hline Plat $\left(10^{6}\right.$ cells/ml $)$ & 302 & 251 & 367 & 301 & 396 & 296 \\
\hline INR & 1.1 & 1.2 & 1.0 & 1.1 & 1.0 & 1.1 \\
\hline APTT (sec) & 31 & 35 & 30 & 33 & 29 & 31 \\
\hline Fib $(\mathrm{m} / \mathrm{dl})$ & 3.7 & 2.1 & 4.1 & 2.0 & 3.6 & 2.4 \\
\hline $\mathrm{ACT}(\mathrm{sec})$ & 135 & 105 & 146 & 110 & 141 & 108 \\
\hline $\mathrm{CPB}(\min )$ & 51 & & 174 & & 56 & \\
\hline $\mathrm{ACC}(\min )$ & 21 & & 120 & & 27 & \\
\hline Blood loss* (ml) & 3400 & & 790 & & 720 & \\
\hline \multicolumn{7}{|c|}{ Transfusions (units) } \\
\hline Platelets & 45 & & 16 & & 23 & \\
\hline FFP & 20 & & 5 & & 0 & \\
\hline Packed cells & 6 & & 4 & & 4 & \\
\hline
\end{tabular}

$H b$, Hemoglobin; Plat; platelet count; INR, International Normalized Ratio APTT; kaolin-based partial thromboplastin time (normal 35 to $55 \mathrm{sec}$ ); Fib; fibrinogen, $A C T$; activated clotting time (normal 105 to $120 \mathrm{sec}$ ); $A C C$, Aortic crossclamp time; FFP, fresh-frozen plasma.

*24-hour mediastinal loss. 
ing urgent $\mathrm{CABG}$ for failed PTCS. ${ }^{3}$ Their operative mortality rate of treated versus placebo groups is disturbing (placebo $8 \%$ versus treated $29.4 \%$ for bolus plus infusion). Claims by the EPIC investigators that these results are acceptable are contradicted by their quoted references. Eight references had operative mortality rates ranging from $0 \%$ to $6.3 \%$. In the remaining two, the Mid America Heart group had a total series operative mortality rate of $6.3 \%(18 / 286) .{ }^{4}$ Of the 113 emergency CABGs, $45 \%$ were performed on patients in cardiogenic shock (mortality rate $15 \%$ ) or receiving cardiopulmonary resuscitation (mortality rate 62\%). The remainder of patients undergoing emergency CABG had a mortality rate of $3 \%$ to $4 \%$. The Mid America Heart group quote the mortality rate for the 1983 National Heart and Lung Institute percutaneous transluminal coronary angioplasty surgical registry as $6.9 \%$. In the series of Buffet and coworkers, ${ }^{5}$ all were emergency cases; $23 \%$ of patients were in cardiogenic shock or requiring cardiopulmonary resuscitation. Excluding these cases in extremis, accounting for 14 of 19 deaths, the operative mortality rate for the remainder of emergency cases was $6.5 \%$.

Thus, the $29.4 \%$ operative mortality rate of the EPIC trial is not reflective of the published mortality rates of $3 \%$ to $6 \%$ for the same group of patients undergoing CABG, particularly because the EPIC patients are not comparable with the in extremis cases reported on by Buffet and coworkers ${ }^{5}$ and the Mid America Heart Institute. ${ }^{4}$ This 30-day, nominal $4 \%$ to $6 \%$ benefit attributed to abciximab for PTCS must be questioned if surgical mortality rate is increased among those needing CABG for failed PTCS.
In addition, blood transfusion costs were $\$ 23,500$ Australian, the cost of abciximab was $\$ 1500$ Australian/case, and three patients were exposed to 131 donors. In Australian public hospitals, $\$ 28,000$ Australian would cover $70 \%$ of the cost of all three CABGs. Trials analyzing the effects of this drug must include data on patients who required urgent $\mathrm{CABG}$ if sensible conclusions are to be reached. Before giving abciximab, the cardiologist must therefore critically assess the risk of PTCS failure, because the impact of abciximab on $\mathrm{CABG}$ is not benign.

\section{REFERENCES}

1. The EPIC Investigators. Use of a monoclonal antibody directed against the platelet glycoprotein IIb/IIIa receptor in high risk coronary angioplasty. N Engl J Med 1994;330: 956-61.

2. Holmes DR Jr. Preventing coronary restenosis and complications. N Engl J Med 1997;336:1748-9.

3. Boehrer JD, Kereiakes DJ, Navetta FI, Califf RM, Topol EJ. Effects of profound platelet inhibition with c7E3 before coronary angioplasty on complications of coronary bypass surgery. Am J Cardiol 1994;74:1166-70.

4. Killen DA, Hamaker WR, Reed WA. Coronary artery bypass following percutaneous transluminal coronary angioplasty. Ann Thorac Surg 1985;40:133-8.

5. Buffet P, Danchin N, Villemon JP, Amrein D, et al. Early and long term outcome after emergency coronary artery bypass surgery after failed coronary angioplasty. Circulation 1991; 84(suppl)III254-9. 